\title{
Phospholipid Composition and $\mathrm{Ca}^{2+}$ Uptake Properties of Plasma Membrane Isolated from Canine Stomach Smooth Muscle
}

\author{
Takayoshi ITo and Yasushi SAKAI \\ 2nd Department of Physiology Showa University, School of \\ Medicine. 1-5 Hatanodai, Tokyo 142, Japan
}

\begin{abstract}
Ito, T. and Sakai, Y. Phospholipid composition and $\mathrm{Ca}^{2+}$ uptake properties of plasma membrane isolated from canine stomach smooth muscle. Japanese Journal of Smooth Muscle Research, 22(1), 11-19. — The $\mathrm{Ca}^{2+}$ uptake and phospholipids influencing it in plasma membrane isolated from canine stomach smooth muscle was investigated. The major phospholipids in plasma membrane were phosphatidylethanolamine (PE, 26\%), phosphatidylcholine (PC, 20\%) and phosphatidylserine+ phosphatidylinositol (PS + PI, 15\%). The cholesterol/phospholipid ratio in the membrane was 0.64. ATP-dependent $\mathrm{Ca}^{2+}$ uptake was inhibited by exogenous PE, PC and PS, but increased by PI. Saponin and phospholipase $\mathrm{C}$ inhibited ATP-dependent $\mathrm{Ca}^{2+}$ uptake and accelerated release of $\mathrm{Ca}^{2+}$ from actively loaded plasma membrane vesicles. In the absence of ATP, PE slightly and PI significantly increased $\mathrm{Ca}^{2+}$ uptake, but $\mathrm{PC}$ and PS did not affect the $\mathrm{Ca}^{2+}$ uptake. Release of $\mathrm{Ca}^{2+}$ from actively loaded vesicles was 5 times greater in the presence of PI than in its absence. Results suggest PI to be the most active of the tested phospholipids in influencing $\mathrm{Ca}^{2+}$ movement across plasma membrane.
\end{abstract}

\section{Introduction}

Investigation of $\mathrm{Ca}^{2+}$ movement across the isolated plasma membrane is the most direct approach to determine the capability of smooth muscle membrane to regulate intracellular $\mathrm{Ca}^{2+}$ and thus control muscle function. We have previously reported that plasma membrane isolated from canine gastric corpus smooth muscle can control intracellular $\mathrm{Ca}^{2+}$ (Sakai et al., 1981) and determined several of the factors that contribute to this control (Sakai et al., 1983, Yasuda and Sakai, 1984). Phospholipids are important in physiological functions of the cell (Coleman, 1973, Cossins and Prosser, 1978), and interrelate structually with proteins and other membrane components. It has been reported that the activity of adenylate cyclase in plasma membrane of mammalian cells depends on its interactions with anionic lipids, particularly phosphatidylinositol (PI) and phosphatidylserine (PS) (Birnbaumer, 1973; Levey, 1972). Hauser and Dawson (1968) found that the displacement of bound $\mathrm{Ca}^{2+}$ by alkali metal ions or

Accepted for publication, February 5, 1986.

伊藤隆義, 坂井 泰: 昭和大学医学部 第二生理学教室, $\bar{\top} 142$ 東京都品川区旗の台 1-5 
some local anesthetics was affected by the molecular conformation of the lipid monolayers. In view of the different functions of the membrane that require specific phospholipids, the distribution of various phospholipids may be important in the control and integration of any vectorial process occurring in the membrane (Dominski et al., 1983). It is therefore important to determine the composition of phospholipids in the membrane and to investigate the effects of excess of individual phospholipids. This latter procedure can be carried out by introducing various individual phospholipids exogenously. The present study was undertaken to investigate the role of phospholipids in the transport of $\mathrm{Ca}^{2+}$ by plasma memebrane isolated from canine gastric corpus smooth muscle.

\section{Materials and Methods}

\section{Membrane preparation}

Plasma membranes were prepared from mongrel dogs $(12-20 \mathrm{~kg})$ by the method of Sakai et al. (1981) with slight modifications. After submucosa and longitudinal muscle were removed, the circular muscle was cut into small pieces, and finely minced. The tissue was homogenized 3 times for $5 \mathrm{sec}$ each time in ice-cold sucrose-MOPS (250 mM sucrose and $20 \mathrm{mM}$ morpholinopropane sulfonic acid-NaOH pH 7.0 $1 \mathrm{~g} / 10 \mathrm{ml}$ ) using a motor driven homogenizer (B. Brawn Model ET-20), and briefly centrifuged at 1,000 $\times \mathrm{g}$ for $10 \mathrm{~min}$ to remove the cell debris and nuclei. The post-nuclear supernatant (PNS) was then centrifuged at $12,000 \times \mathrm{g}$ for $10 \mathrm{~min}$ to sediment the mitochondrial fraction (MIT) and subsequently at $140,000 \times \mathrm{g}$ for $60 \mathrm{~min}$ to separate the crude microsomal fraction. The crude microsomal fraction was then resuspended and centrifuged at $10,000 \times \mathrm{g}$ again for $10 \mathrm{~min}$ to obtain the refined microsomal fraction as the supernatant. This was placed on top of a discontinuous sucrose density gradient $(18 \%, 32 \%$, $40 \%, 60 \%)$ and centrifuged at $112,000 \times \mathrm{g}$ for $2 \mathrm{hr}$. The plasma membrane enriched fraction was obtained from the interphases of the sucrose layers. These fractions have been previously characterized (Sakai et al., 1981).

\section{Lipid extraction from isolated plasma membrane}

The lipids were extracted from the suspended plasma membrane buffer with a 3-fold volume of chloroform/methanol $(2: 1, \mathrm{v} / \mathrm{v})$ as described by Folch et al. (1968). The lipid extract was dissolved in chloroform, washed with $0.9 \% \mathrm{NaCl}$, and the upper layer was discarded. The lower layer was then evaporated under $\mathrm{N}_{2}$ gas at $30-32^{\circ} \mathrm{C}$. The lipids were separated by thin-layer chromatography using a silca-gel G plate (Merck, Darmstadt) and developed with pertoleum ether/ether/acetic acid $(80: 30: 1, \mathrm{v} / \mathrm{v})$. Total phospholipids were visualized by exposure to iodine vapour. The spots were scraped from the plates and extracted three times with chloroform/methanol $(2: 1)$ and once with ether. The extract was evaporated under $\mathrm{N}_{2}$ gas at $30-32^{\circ} \mathrm{C}$ then dissolved with chloroform again. Specific phospholipids were then separated by thin-layer chromatography using a silica-gel $\mathrm{G}$ plate and developed with chloroform/methanol/acetic acid/water $(25: 15: 4: 2, \mathrm{v} / \mathrm{v})$. Phospholipids were visualized by exposure to iodine vapour. The spots were scraped from the plates and analyzed for phosphate content by the method of Bartlett (1959). Cholesterol content was measured by the method of Sperry and Webb (1950). 


\section{$\mathrm{Ca}^{2+}$ uptake measurement}

$\mathrm{Ca}^{2+}$ accumulation by isolated subcellular membrane fractions was assayed using a filtration technique previously described (Yasuda and Sakai, 1984). A typical reaction mixture contained $250 \mathrm{mM}$ sucrose, $40 \mathrm{mM}$ imidazole- $\mathrm{HCl}, 5 \mathrm{mM} \mathrm{Na}$ ATP, $5 \mathrm{mM} \mathrm{MgCl}_{2}$ and $100 \mu \mathrm{M}$ $\mathrm{CaCl}_{2}$ labelled with ${ }^{45} \mathrm{CaCl}_{2}(0.2-1 \mu \mathrm{Ci})$ at $\mathrm{pH}$ 7.0. This gave a calculated concentration of about $20 \mu \mathrm{M}$ free $\mathrm{Ca}^{2+}$ (Janis et al., 1977). When $\mathrm{Na}_{2}$ ATP was not used, only $20 \mu \mathrm{M} \mathrm{CaCl}_{2}$ was used. To study the effects of saponin and phospholipase $\mathrm{C}$, these compounds were added to the $\mathrm{Ca}^{2+}$ reaction medium. The typical $\mathrm{Ca}^{2+}$ assay procedure was as follows: With constant shaking, $50 \mu \mathrm{l}$ of membrane fraction containing $20-50 \mu \mathrm{g}$ of protein was added to $200 \mu \mathrm{l}$ medium. After $10 \mathrm{~min}$ incubation at $37^{\circ} \mathrm{C}$, the $200 \mu \mathrm{l}$ suspension was filtered on Millipore filters (TOYO TYPE TM-2 $0.45 \mu \mathrm{m}$ pore size) which had been stored in $0.1 \mathrm{M} \mathrm{KCl}$ solution and washed just before the experiment with sucrose/IM solution. The filters were then washed twice with $5 \mathrm{~m} l$ of the sucrose/IM solution. Radioactivity on the filters and in the incubation medium was measured in Bray's solution (Bray, 1960). The radioactivity on the filters without membrane protein was subtracted. Protein was determined by the method of Lowry et al. (1951) using bovine serum albumin as a standard.

\section{Materials}

Saponin was purchased from Wako Pure Chemical Industry. $\mathrm{Na}_{2}-\mathrm{ATP}, \mathrm{MOPS}$ and phosphatidylinositol were purchased from Sigma. Phosphatidylcholine, phosphatidylethanolamine and phsphatidylserine were purchased from Tokyo Kasei Kogyo. ${ }^{45} \mathrm{CaCl}_{2}$ was purchased from New England Nuclear. All other reagents were purchased in the purest form available from standard commercial sources.

\section{Results}

\section{Phospholipid composition of plasma membrane}

The content of phospholipids and cholesterol in the membrane was determined in five

Table 1. Composition of phospholipids in the plasma membrane isolated from canine stomach

\begin{tabular}{l|c}
\hline Phospholipid composition & $\begin{array}{c}\% \text { of total } \\
\text { phospholipids }\end{array}$ \\
\hline Phosphatidylethanolamin & $26.1 \pm 0.8$ \\
Phosphatidylcholine & $19.5 \pm 0.2$ \\
Phosphatidylserine & $15.2 \pm 0.2$ \\
$\quad$ Phosphatidylinositol & $13.4 \pm 0.3$ \\
Sphingomyelin & $13.9 \pm 0.5$ \\
Lysophosphatidylcholine & $11.8 \pm 0.4$ \\
\hline
\end{tabular}

Data are mean $\pm \mathrm{SE}$ in the five separate preparations.
Table 2. Effects of saponin and phospholipase C on $\mathrm{Ca}^{2+}$ uptake

\begin{tabular}{c|c|c}
\hline \multirow{2}{*}{ Treatment } & \multicolumn{2}{|c}{$\begin{array}{c}\mathrm{Ca}^{2+} \text { uptake } \\
(\mu \mathrm{mol} / \mathrm{g} \text { protein } / 10 \mathrm{~min})\end{array}$} \\
\cline { 2 - 3 } & $\begin{array}{l}\text { ATP- } \\
\text { dependent }\end{array}$ & $\begin{array}{l}\text { ATP- } \\
\text { independent }\end{array}$ \\
\hline Control & $42.7 \pm 0.3$ & $1.7 \pm 0.1$ \\
Saponin & $32.1 \pm 0.5$ & $1.6 \pm 0.1$ \\
$25 \mu \mathrm{g} / \mathrm{m} l$ & $19.4 \pm 1.2$ & $1.7 \pm 0.1$ \\
$50 \mu \mathrm{g} / \mathrm{m} l$ & $45.1 \pm 0.2$ & $1.6 \pm 0.1$ \\
Phospholipase C & $34.7 \pm 0.7$ & $1.7 \pm 0.1$ \\
\hline $100 \mu \mathrm{g} / \mathrm{m} l$ & $\mathrm{~m} l$ & 34.7 \\
\hline
\end{tabular}

Plasma membrane were treated by saponin or phospholipase $\mathrm{C}$ for $10 \mathrm{~min}$. Data are mean $\pm \mathrm{SE}$ $(\mathrm{n}=4)$. 
separate preparations. The cholesterol/phospholipid ratio in the plasma membrane isolated from canine stomach smooth muscle was 0.64 . The composition of phospholipids was as shown in Table 1. The phospholipids separated and identified were: phosphatidylethanolamine (PE), phsophatidylcholine (PC), phosphatidylserine (PS) plus phsophatidylinositol (PI), sphingomyeline (SM), and lysophosphatidylcholine (LPC). The major phospholipid was PE. PS and PI could not be clearly separated by the method used, so we show the content of these two phospholipids thgether in Table 1. The LPC content was high compared to that in membrane from other tissue.

\section{Effect of saponin and phospholipase $\mathrm{C}$ on $\mathrm{Ca}^{2+}$ uptake}

Table 2 shows the effects of saponin and phsopholipase $\mathrm{C}$ on $\mathrm{Ca}^{2+}$ uptake by plasma membrane isolated from canine stomach smooth muscle. Saponin inhibited ATP-dependent $\mathrm{Ca}^{2+}$ uptake dose dependently. $50 \mu \mathrm{g} / \mathrm{m} l$ of phospholipase $\mathrm{C}$ increased ATP-dependent $\mathrm{Ca}^{2+}$ uptake slightly but significantly. Higher doses of phospholipase C inhibited ATP-dependent $\mathrm{Ca}^{2+}$ uptake. ATP-independent $\mathrm{Ca}^{2+}$ uptake was not affected by these substances after $10 \mathrm{~min}$ treatment.

\section{Release of $\mathrm{Ca}^{2+}$ from actively loaded plasm membrane vesicles}

To determine membrane permeability to $\mathrm{Ca}^{2+}$, we studied the release of $\mathrm{Ca}^{2+}$ from plasma membrane vesicles that had been preloaded with ${ }^{45} \mathrm{Ca}^{2+}$ for $10 \mathrm{~min}$ and then diluted to 0.1 of the initial concentration in isotonic buffer in the presence of saponin or phospholipase C. As

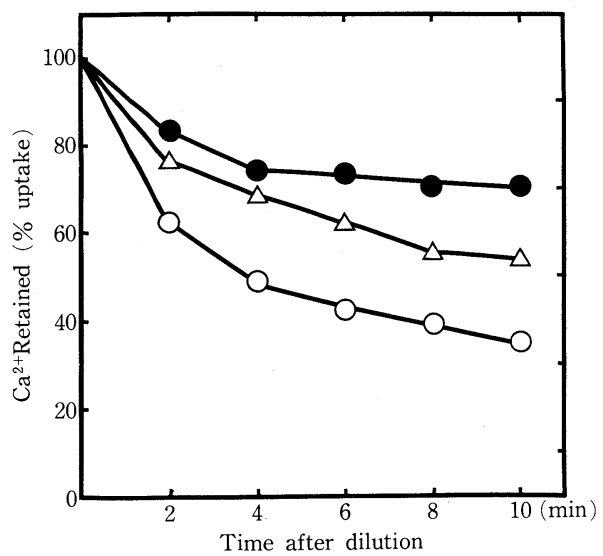

Fig. 1. Time-dependent release of $\mathrm{Ca}^{2+}$ from actively loaded plasma membrane vesicles. Plasma membrane $(60-100 \mu \mathrm{g}$ protein) added to $1 \mathrm{ml}$ of standard reaction mixture. After $10 \mathrm{~min}$ of $\mathrm{Ca}^{2+}$ uptake, aliquotes were either filtered directly to determine total $\mathrm{Ca}^{2+}$ uptake or diluted in isotonic buffer containing phospholipase $\mathrm{C}$ or saponin. Control, $(\bullet)$; phospholipase $\mathrm{C},(\triangle)$; saponin, (O).

Table 3. Effects of exogenous phospholipids on $\mathrm{Ca}^{2+}$ uptake

\begin{tabular}{lc|c|c}
\hline \multirow{2}{*}{ Treatment } & \multicolumn{2}{c}{$\mathrm{Ca}^{2+}$ uptake $(\mu \mathrm{mol} / \mathrm{g}$ protein $/ 10 \mathrm{~min})$} \\
\cline { 3 - 4 } & & ATP-dependent & ATP-independent \\
\hline Control & & $46.6 \pm 0.4$ & $1.2 \pm 0.2$ \\
Phosphatidylethanolamine & $15 \mu \mathrm{g} / \mathrm{m} l$ & $28.6 \pm 0.6$ & $1.6 \pm 0.1$ \\
Phosphatidylserine & $15 \mu \mathrm{g} / \mathrm{m} l$ & $27.9 \pm 3.3$ & $1.4 \pm 0.1$ \\
Phosphatidylcholine & $45 \mu \mathrm{g} / \mathrm{m} l$ & $30.8 \pm 0.4$ & $1.1 \pm 0.2$ \\
\hline
\end{tabular}

Data are mean $\pm \mathrm{SE}(\mathrm{n}=5)$. Ca uptake reaction media contained phospholipid suspension (chloroform : methanol, 2:1). 
shown in Fig. 1, saponin and phospholipase $\mathrm{C}$ increased the release of $\mathrm{Ca}^{2+}$ from vesicles. Saponin was more effective than phospholipase $\mathrm{C}$ and the amount of $\mathrm{Ca}^{2+}$ retained in vesicles in the presence of saponin was about the same as that taken up after 10 min dilution (Table 2).

\section{Effects of exogenous phospholipids on $\mathrm{Ca}^{2+}$ uptake}

Table 3 shows the $\mathrm{Ca}^{2+}$ uptake by plasma membrane isolated from canine stomach in the presence and absence of each phospholipid. All three phospholipids inhibited ATP-dependent $\mathrm{Ca}^{2+}$ uptake. Exogenous $\mathrm{PC}$ inhibited $\mathrm{Ca}^{2+}$ uptake with about one third the potency of PE or PS, which were nearly the same. ATP-independent $\mathrm{Ca}^{2+}$ uptake was small, and PE accelerated this uptake slightly but significantly.

\section{Effects of exogenous $P E, P S$ and PI on $\mathrm{Ca}^{2+}$ release from actively loaded plasma membrane}

Figure 2 shows the results of experiments in which $\mathrm{Ca}^{2+}$ was released from actively loaded

Fig. 2. Rate of release of $\mathrm{Ca}^{2+}$ from actively loaded vesicles in the presence of various phospholipids. Release in control and in presence of PE and PS measured from $15 \mathrm{sec}$ to $5 \mathrm{~min}$, and in presence of PI from $15 \mathrm{sec}$ to 2 min. Phospholipids were suspended in isotonic buffer by sonication. $100 \mu \mathrm{g} / \mathrm{m} l$ final concentration was used. Data are mean \pm SE $(n=3-4)$.

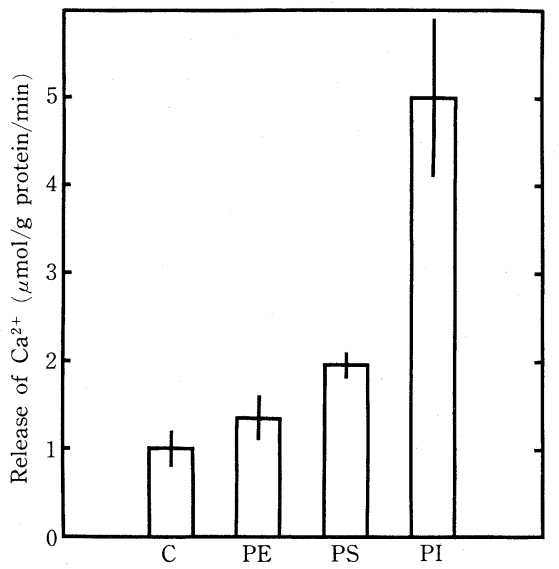

vesicles diluted to 0.1 concentration in isotonic solution containing $\mathrm{PE}$ or PS or PI. These solutions were prepared by dissolving the appropriate phospholipid in chloroform/methanol (2 : $1, \mathrm{v} / \mathrm{v}$ ) and then suspending the solution in isotonic buffer by sonication. The data in Fig. 2 were obtained from the ratio of $\mathrm{Ca}^{2+}$ retained in solution to the total $\mathrm{Ca}^{2+}$ uptake between 15 sec and $5 \mathrm{~min}$ for the control, PE and PS; and between $15 \mathrm{sec}$ and $2 \mathrm{~min}$ for PI. Release of $\mathrm{Ca}^{2+}$ from plasma membrane vesicles was accelerated by all these phospholipids, but significantly by only PS and PI. Release of $\mathrm{Ca}^{2+}$ by PS was about 2 times, and by PI about 5 times that of the control. The results thus show that these two phospholipids alter plasma membrane permeability to $\mathrm{Ca}^{2+}$.

\section{Effects of exogenous PI on $\mathrm{Ca}^{2+}$ movement}

It is well known that turnover of PI is faster than that of other phospholipids. In this study, we could not clearly separate endogenous PI from PS in isolated plasma membrane by TLC. However, exogenous PI affected the movement of $\mathrm{Ca}^{2+}$ relative to plasma membrane more than the other phospholipids tested. Figure 3 shows the ATP-dependent and ATP- 


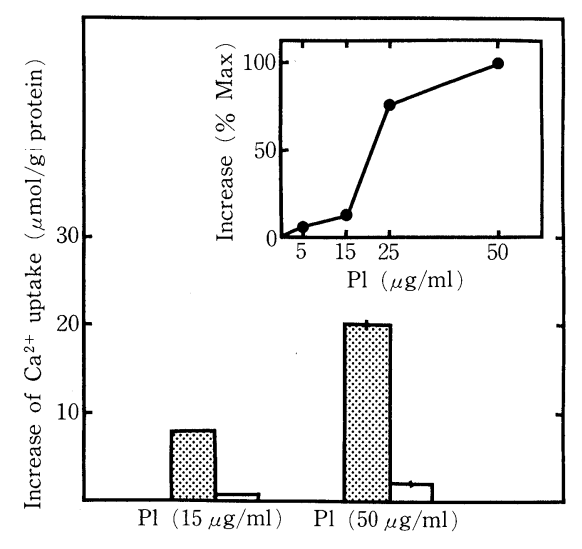

Fig. 3. Increase of $\mathrm{Ca}^{2+}$ uptake by plasma membrane in the presence of sonicated PI. ATP-dependent $\mathrm{Ca}^{2+}$ uptake ( $\because$ ), ATP-independent $\mathrm{Ca}^{2+}$ uptake ( $\square$ ). PI was dissolved in chloroform/methanol $(2: 1, \mathrm{v} / \mathrm{v})$ and the solution was suspended in the reaction mixture. Inset shows $\mathrm{Ca}^{2+}$ uptake by the sonicated preparations of $\mathrm{PI}$ in the presence of $20 \mu \mathrm{M}$ free $\mathrm{Ca}^{2+}$. Data are mean $\pm \operatorname{SE}(n=4)$.

Fig. 4. Effects of PI and neomycin on $\mathrm{Ca}^{2+}$ uptake by plasma membrane in the presence absence of ATP. Control, $(\square) ; 15 \mu \mathrm{g} / \mathrm{m} l$ PI, (ㅁil) ; $5 \mathrm{mM}$ neomycin, ( $\because) ; 15 \mu \mathrm{g} / \mathrm{m} l$ $\mathrm{PI}+5 \mathrm{mM}$ neomycin, $(\mathbb{\$})$ Data are mean \pm $\mathrm{SE}(\mathrm{n}=5-9)$.

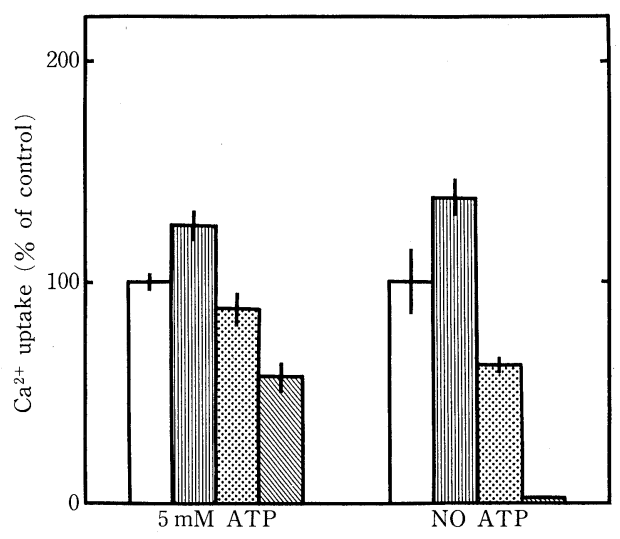

indenpendent increase of $\mathrm{Ca}^{2+}$ uptake in the presence of PI. $\mathrm{Ca}^{2+}$ uptake was increased the same by the same cencentrations of PE and PS (Table 3), and increased more in both cases in the presence of higher doses (not shown). Fig. 3 inset shows the dose dependence of $\mathrm{Ca}^{2+}$ uptake by PI alone. Comparison of the results in Table 3 and Fig. 3 show that PI was much more effective than either PE or PS in increasing $\mathrm{Ca}^{2+}$ uptake by plasma membrane. The antibiotic, neomycin, binds strongly to PI and prevents both PI metabolism and PI function (e. g. $\mathrm{Ca}^{2+}$ uptake). Figure 4 shows the effects of neomycin on ATP-dependent and ATP-independent $\mathrm{Ca}^{2+}$ uptake in the presence and absence of PI. PI increased $\mathrm{Ca}^{2+}$ uptake in both the presence and absence of ATP as shown in Figs. 3 and 4. Neomycin inhibited $\mathrm{Ca}^{2+}$ uptake by plasma membrane in the presence and absence of ATP (Fig. 4). This inhibition by neomycin was greater (both absolutely and relatively) in the presence of PI, and $\mathrm{Ca}^{2+}$ uptake in the absence of ATP was almost undetectable.

\section{Discussion}

The plasma membrane used in this study was capable of ATP-dependent, active transport of $\mathrm{Ca}^{2+}$ into the vesicles. We have previously reported the $\mathrm{Km}$ for $\mathrm{Ca}^{2+}$ this transport to be $0.85 \pm 0.01 \mu \mathrm{M}$ which is appropriate for control of intracellular $\mathrm{Ca}^{2+}$, and the $\mathrm{Ca}^{2+}$ gradients achievable were in the range of 500 to $2,000\left(\mathrm{Ca}_{\mathrm{i}}{ }^{2+}: \mathrm{Ca}_{0}{ }^{2+}\right)$, comparable to those across plasma 
membrane (Grover et al., 1980; Kwan et al., 1982; Sakai et al., 1983). We measured a cholesterol/phospholipids ratio of 0.64 . Raeymaekers et al. (1983) reported that the cholesterol/phospholipid ratio in plasma membrane isolated from pig stomach smooth muscle was 0.52 which was 2.5 times that in the endoplasmic reticulum.

The major phospholipids were PE, PC, PS and PI which together composed more than $60 \%$ of the total lipid of the plasma membrane isolated from canine stomach smooth muscle (Table 1). There are considerable differences between our preparation and other plasma membrane preparations (Carmel et al., 1985; Schick et al., 1976). The content of PC in our canine stomach preparation was substantially less than the content in skeletal or cardiac plasma membrane (Hotta and Usami, 1967 ; Barr et al., 1974) (PC 45.0\%, PE 22.6\%, PI+SM 22.2\%, PS $8.6 \%$, phosphatidic acid 1.5\%). As far as we know, there is no report of phospholipid composition of plasma membrane isolated from smooth muscle. The high level of LPC was not an artifact but is inherent in the nature of plasma membrane that is high in cholesterol, and cholesterol and LPC associate in a 1:1 molar ratio (Ramsammy and Brockerhoff, 1982). LPC is known to lyse membranes, and cholesterol prevents such lysis (Chauhan et al., 1984). Saponin inhibited ATP-dependent $\mathrm{Ca}^{2+}$ uptake (Table 2) and accelerated release of $\mathrm{Ca}^{2+}$ from preloaded vesicles (Fig. 1). Saponin binds to cholesterol to form a ring with a central hydrophilic hole in a micellar-type arrangement (Glauert et al., 1962). ATP-dependent $\mathrm{Ca}^{2+}$ uptake by plasma membrane was inhibited about $50 \%$ by $50 \mu \mathrm{g} / \mathrm{ml}$, and retained $\mathrm{Ca}^{2+}$ after 10 min dilution was also $50 \%$ in the presence of the same concentratdon of saponin (Table 2 and Fig. 1). Saponin might make the plasma membrane leaky.

Phospholipase C hydrolyzes PC, PE and SM (Rosenberg and Condrea, 1968) which comprise more than half of the total phospholipids of the plasma membrane. ATP-dependent $\mathrm{Ca}^{2+}$ uptake by plasma membrane was inhibited by $100 \mu \mathrm{g} / \mathrm{m} l$ phospholipase C (Table 2). This effect was weaker than previously reported (Sakai et al., 1982) which might be due to the difference between inside-out and outside-out vesicles. There is asymmetry of phospholipids in the plasma membrane. It is reported that PC and SM are present in the outer surface and $\mathrm{PS}$ and PE are in the inner surface of the platelet plasma membrane (Shick et al., 1976). However, Schick et al. did not evaluate the inner and outer proportions of PI. ATP-dependent $\mathrm{Ca}^{2+}$ uptake is assumed to be due to the presence of inside-out vesicles in our preparations and presumably reflects the activity of an outwardly directed $\mathrm{Ca}^{2+}$ pump in plasma membrane, since this $\mathrm{Ca}^{2+}$ uptake is inhibited by $\mathrm{Ca}^{2+}$ ionophores which dissipate the $\mathrm{Ca}^{2+}$ gradient across the membrane vesicles (Sakai et al., 1981; Kwan et al., 1982). Therefore, the results of our study using inside-out vesicles might be different from a similar study using outside-out vesicles.

It has become clear that the activity of adenylate cyclase in plasma membranes of mammalian cells depends on its interactions with anionic lipids, particularly PI and PS. Hormone and neurotransmitter enhancement has shown PI turnover and increased $\mathrm{Ca}^{2+}$ influx in guinea pig ileum and rat vas deferens smooth muscle (Jafferji and Michell, 1976 ; Canessa de Scarnati and Lapetina, 1974). The mechanism of PI breakdown in the plasma membrane must be confirmed in a variety of systems and its early kinetics investigated. PI breakdown is not apparently being controlled by changes in extracellular or intracellular $\mathrm{Ca}^{2+}$ and therefore its role, if it lies in the main sequence of events which mediate receptor responsiveness, must be 
either intracellular liberation of membrane-bound $\mathrm{Ca}^{2+}$ or opening of the $\mathrm{Ca}^{2+}$ gates (Michell, 1975). PI increased and neomycin decreased $\mathrm{Ca}^{2+}$ uptake by plasma membrane (Figs. 2 and 3 ). The results in Fig. 4 strongly suggest that PI replaced other phospholipids or fused into the membrane in our preparations. Simple increase of $\mathrm{Ca}^{2+}$ uptake by PI could occur if the PI was bound to the membrane surface, but the increase of neomycin inhibition of $\mathrm{Ca}^{2+}$ uptake by PI can only be explained by replacement or fusion. Results suggest that PI is important in for $\mathrm{Ca}^{2+}$ movement across the plasma membrane, and are consistent with the known high metabolism and turnover of PI.

Acknowledgements: The authors wish thank Miss A Isobe for her excellent technical assistance and Dr. A. Simpson for help in preparing the manuscript.

\section{References}

Barr, L., Connor, J.A., Dewey, M.M., Aprille, J. and Johnston, P.V. (1974). The Isolation of plasma membrane from frog cardiac muscle cells. Biochim. Biophys. Acta 345: 336-347.

Bartlett, G.R. (1959). Phosphorus assay in column chromatography. J. Biol. Chem. 234 : 466-468.

Birnbaumer, L. (1973). Hormone-sensitive adenyl cyclases useful models for studying hormone receptor functions in cell-free systems. Biochim. Biophys. Acta 300 : 129-158.

Bray, G.A. (1960). A simple efficient liquid scintillator for counting aqueous solutions in a liquid scintillation counter. Anal. Biochem. 1: 279-285.

Canessa, de Scarnati, O. and Lapetina, E.G. (1974). Adrenergic stimulation of phosphatidylinositol labelling in rat vas deferens. Biochim. Biophys. Acta 360 : 298-305.

Carmel, G., Rodrigue, F., Carriere, S. andd Le Grimellec, C. (1985). Composition and physical properties of lipids from plasma membranes of dog kidney. Biochim. Biophys. Acta 818 : 149-157.

Chauhan, V.P.S., Ramsammy, L.S. and Brackerhoff, H. (1984). Molecular interactions in the hydrogen belts of membranes glucose-6-phosphatase, lysophophatidylcholine, and cholesterol. Biochim. Biophys. Acta 772 : 239-243.

Coleman, R. (1973). Membrane-bound enzymes and membrane ultrastructure. Biochim. Biophys. Acta 300 : 1-30.

Cossins, A.R. and Prosser, C.L. (1978). Evolutionary adaptation of membranes to temperature. Proc. Natl. Acad. Sci. USA 75 : 2040-2043.

Dominshki, J., Binaglia, L., Dreyfus, H., Massarelli, R., Mersel, M. and Ereysy, L. (1983). A study on the topological distribution of phospholipids in microsomal membranes of chick brain using phosphoolipase $\mathrm{C}$ and trinitrobenzenesulfonic acid. Biochim. Biophys. Acta 743 : 257-266.

Folch, J., Lees, M. and Stanley, G.H.S. (1957). A simple method for the isolation and purification of total lipids from animal tissues. J. Biol. Chem. $226:$ 497-509.

Glauert, A.M., Dingle, J.T. and Lucy, J.A. (1962). Action of saponin on biological cell membranes. Nature London 196 : 953-955.

Gordeshy, S.E. and Marinetti, G.V. (1973). The asymetric arrangement of phospholipids in the human erythrocyte membrane. Biochem. Biophys. Res. Commun. 88: 1132-1139.

Grover, A.K., Kwan. C.Y., Crankshaw, J., Crankshaw, D.J., Garfield, R.E. and Daniel, E.E. (1980). Characteristics of calcium transport and binding by rat myometrium plasma membrane subfractions. Am. J. Physiol. 239 (Cell Physiol. 8) : c66-c74.

Hauser, H. and Dawson, R.M.C. (1968). The displacement of calcium ions from phospholipid monolayers by pharmacologically active and other organic bases. Biochem. J. 109 : 909-916.

Hotta, K. and Usami, Y. (1967). Enzymatic activity of isolated skeletal muscle sarcolemma. J. 
Biochem. 61: 407-410.

Jafferji, S.S. and Michell, R.H. (1976). Muscarinic cholinergic stimulation of phosphatidylinositol turnover in the longitudinal smooth muscle of guinea-pig ileum. Biochem. J. 154: 653-657.

Janis, R.A., Crankshaw, D.J. and Daniel. E.E. (1977). Control of intracellular calcium activity in rat myometrium. Am. J. Physiol. 232 (Cell Physiol. 1) : c50-c58.

Kwan, C.Y., Sakai, Y., Grover, A.K. and Lee, R.M.K.W. (1982). Isolation and characterization of plasma membrane fraction from gastric fundus smooth muscle of the rat. Mol. Physiol. 2 : 107-120.

Levey, G.S. (1972). In : the role of membranes in metabolic regulation, edited by M.A. Mehlman, and R.W. Hanson, pp. 249-260, Academic Press, New York.

Lowry, O.H., Rosebrough, N.J., Farr, A.L. and Randall, R.J. (1951). Protein measurement with the folin phenol reagent. J. Biol. Chem. 193: 265-275.

Michell, R.H. (1975). Inositol phospholipids and cell surfase receptor function. Biochim. Biophys. Acta 415 : 81-147.

Raeymaekers, L., Wuytack, F., Eggermont, J., Schutter, G.D. and Casteels, R. (1983). Isolation of plasma-membrane fraction from gastric smooth muscle: Comparison of the calcium uptake with that in endoplasmic reticulum. Biochem. J. $210: 315-322$.

Ramsammy, L.S. and Brockerhoff, H. (1982). Lysophosphatidylcholine-cholesterol complex. J. Biol. Chem. 257 : 3570-3574.

Rosenberg, P. and Condrea, E. (1968). Maintenance of axonal conduction and membrane permeability in presence of fextensive phospholipid splitting. Biochem. Pharmacol. 17 : 2033-2044.

Sakai, Y., McLean, J., Grover, A.K., Garfield, R.E., Fox, J.E.T. and Daniel, E.E. (1981). Isolation and characterization of subcellular membranes from canine stomach smooth muscle. Can. J. Physiol. Pharmacol. 59: 1260-1267.

Sakai, Y., Ichikawa, S., Yoshida, M., Oouchi, M. and Miyagawa, M. (1982). ATPase activity and calcium uptake of microsomes isolated from stomach smooth muscle after exposure to phospholipase C. Jap. J. Smooth Muscle Res. 18 : 339-345.

Sakai, Y., Grover, A.K., Fox, J.E.T. and Daniel, E.E. (1983). Uptake and release of calcium by canine gastric corpus smooth muscle plasma membrane enriched fraction. Can. J. Physiol. Pharmacol. $61: 699-704$.

Schick, P.K., Kurica, K.B. and Chacko, G.K. (1976). Location of phosphatidylethanolamine and phosphatidylserine in the human platelet plasma membrane. J. Clin. Invest. 57 : 1221-1226.

Sperry, W.M. and Webb, M. (1950). A revision of schoenheimersperry method for cholesterol determination. J. Biol. Chem. 187 : 97-106.

Yasuda, N. and Sakai, Y. (1984). A possible explanation for effects of $\mathrm{Sr}^{2+}$ on contraction-relaxation cycle in canine stomach. Comp. Biochem. Physiol. 78A : 35-41. 